\title{
Stage IIC Testicular Cancer AJCC v8
}

National Cancer Institute

\section{Source}

National Cancer Institute. Stage I/C Testicular Cancer A/CC v8. NCI Thesaurus. Code C140236.

Stage IIC includes: (Any pT/TX, N3, M0, S0); (Any pT/TX, N3, M0, S1). TX: Testicular cancer in which the primary tumor cannot be assessed. N3: T esticular cancer with metastasis with a lymph node mass larger than $5 \mathrm{~cm}$ in greatest dimension. M0: Testicular cancer without evidence of distant metastasis. S0: Marker study levels within normal limits. S1: LDH less than $1.5 \times \mathrm{N}$ and $\mathrm{hCG}(\mathrm{mlU} / \mathrm{mL})$ less than 5,000 and AFP (ng/mL) less than 1,000. $\mathrm{N}$ indicates the upper limit of normal for the LDH assay. (AJCC 8th ed.) 